DOI: https://doi.org/10.12797/Politeja.15.2018.54.26

Olesia TKACHUK

Uniwersytet Jagielloński

olesia.tkachuk@doctoral.uj.edu.pl

\title{
ZNACZENIE TRAKTATU LIZBOŃSKIEGO DLA ROZWOJU WSPÓŁPRACY MIĘDZY UNIĄ EUROPEJSKĄ A JEJ PAŃST WAMI SĄSIEDZKIMI
}

ABSTRACT The importance of the Treaty of Lisbon for the development of cooperation between the European Union and neighbouring countries

This article aims to analyse the importance of the Treaty of Lisbon which was signed as of 13th of December 2007 for the development of cooperation between the European Union and neighbouring countries within the framework of the European Neighbourhood Policy in legal and institutional terms. The first part of the article represents the provisions of analysed the Reform Treaty, which regulates the Union's cooperation with third countries and international organisations, in particular art. $8 \mathrm{TEU}$. The following part of the article presents institutional changes insertion by the Treaty of Lisbon, among others, establishing a position of the High Representative of the Union for Foreign Affairs and Security Policy and appointment of European External Action Service. The summary of the above considerations is located at the end of the article.

Keywords: Treaty of Lisbon, European Neighbourhood Policy, European Union, neighbouring countries

Słowa kluczowe: traktat lizboński, Europejska Polityka Sąsiedztwa, Unia Europejska, państwa sąsiedzkie 


\section{UWAGI WSTĘPNE}

Współpraca między Unią Europejską (UE) a państwami sąsiedzkimi, położonymi zarówno na południu, jak i na wschodzie, rozwija się w ramach Europejskiej Polityki Sąsiedztwa (EPS). Jej założenia i cele zawarto w dokumencie zatytułowanym Europejska Polityka Sąsiedztwa. Dokument Strategiczny ${ }^{1}$, przyjętym 12 maja 2004 r. Stwierdzono w nim, że podstawowymi celami EPS są: zacieśnianie dialogu politycznego między UE a państwami sąsiedzkimi, wsparcie przemian demokratycznych w tych krajach, pogłębianie kooperacji gospodarczej oraz w sferze m.in. środowiska i nieproliferacji broni masowego rażenia, a tym samym dążenie do wzmocnienia stabilności i bezpieczeństwa w regionie, rozwijania przyjaznych stosunków oraz utworzenia strefy dobrobytu otaczającej Unię od południa i wschodu ${ }^{2}$. Z kolei wśród zasad omawianej polityki wymieniono: zróżnicowane traktowanie każdego państwa sąsiedzkiego ze względu na jego sytuację wewnętrzną oraz postępy we wdrażaniu poszczególnych reform, a także ciągłość i współwłasność (wspólne wyznaczanie celów wzajemnej współpracy) ${ }^{3}$. Do instrumentów EPS zaliczono natomiast: raporty krajowe, plany działania i raporty okresowe $e^{4}$. W perspektywie finansowej 2014-2020 na pomoc udzielaną państwom sąsiedzkim w ramach EPS wydzielono 15,4 mld euro5.

Europejską Politykę Sąsiedztwa skierowano do następujących państw: Algierii, Armenii, Azerbejdżanu, Białorusi, Egiptu, Gruzji, Izraela, Jordanii, Libanu, Libii, Mołdawii, Maroko, Syrii, Tunezji, Ukrainy oraz Autonomii Palestyńskiej. Federacja Rosyjska sprzeciwiła się przyłączeniu do EPS, chcąc kształtować relacje z Unią Europejską na odrębnych zasadach, w związku z czym współpraca między UE a Rosją do tej pory jest rozwijana na podstawie Układu o partnerstwie i współpracy, który wszedł w życie w $1997 \mathrm{r}^{6}$

Communication from the Commission, European Neighbourhood Policy. Strategy Paper, Brussels, 12 V 2004, $\operatorname{COM(2004)~} 373$ final, s. 1-35.

2 P. Marcinkowska, Europejska Polityka Sasiedztwa. Unia Europejska i jej sasiedzi - wzajemne relacje i wyzwania, Warszawa 2011, s. 21-23; I. Lyubashenko, Europejska Polityka Sasiedztwa Unii Europejskiej wobec państw Europy Wschodniej, Toruń 2012, s. 40-42; tenże, Podstawy normatywne Europejskiej Polityki Sasiedztwa, [w:] Europejska Polityka Sasiedztwa Unii Europejskiej, red. M. Pietraś, K. Stachurska-Szczesiak, J. Misiągiewicz, Lublin 2012, s. 25-26; O. Tkachuk, Europejska Polityka Sasiedztwa, [w:] Polityki europejskie. Perspektywa finansowa UE 2014-2020, red. A. Nitszke, Kraków 2015, s. 243-245; O. Tkachuk, „Uktad o Stowarzyszeniu między Uniq Europejska a Ukraina” - najważniejsze postanowienia oraz znaczenie dla Ukrainy, [w:] Ukraina. 25 lat na drodze niepodlegtości, red. P. Pietnoczka, H. Stroński, Olsztyn 2017, s. 94.

3 I. Lyubashenko, Europejska Polityka Sąsiedztwa..., s. 42; tenże, Podstawy normatywne..., s. 25; O. Tkachuk, Europejska Polityka Sasiedztwa..., s. 245.

4 P. Marcinkowska, Europejska Polityka Sasiedztwa..., s. 40-43.

5 O. Tkachuk, Europejska Polityka Sąiedztwa..., s. 255-258; K. Bartczak, K. Jongberg, Dokumenty informacyjne o Unii Europejskiej - 2017. Europejska Polityka Sąsiedztwa, Parlament Europejski, s. 2, [online] http://www.europarl.europa.eu/RegData/etudes/fiches_techniques/2013/060504/04A_ FT(2013)060504_PL.pdf, 11 V 2018.

6 P. Marcinkowska, Europejska Polityka Sasiedztwa..., s. 20-21; O. Tkachuk, Europejska Polityka Sąsiedztwa..., s. 245; B. Piskorska, Implikacje Europejskiej Polityki Sasiedztwa dla "partnerstwa strategicznego" 
Z czasem UE podjęła kroki na rzecz zwiększenia efektywności EPS i pogłębienia współdziałania z wymienionymi krajami. W wyniku podjętych działań w 2008 r. opracowano dwa programy mające na celu zacieśnienie kooperacji z państwami sąsiedzkimi poszczególnych regionów: Unię dla Śródziemnomorza (państwa basenu Morza Śródziemnego) i Partnerstwo Wschodnie (państwa poradzieckie, takie jak: Armenia, Azerbejdżan, Białoruś, Gruzja, Mołdawia oraz Ukraina). Natomiast po tym, jak wszedł w życie traktat lizboński, EPS doświadczyła kolejnych zmian?

Celem niniejszego artykułu jest analiza znaczenia traktatu lizbońskiego dla rozwoju współpracy między UE a jej państwami sąsiedzkimi w ramach EPS pod względem prawno-instytucjonalnym.

\section{PODSTAWY TRAKTATOWE ROZWOJU WSPÓŁPRACY MIĘDZY UNIĄ EUROPEJSKĄ A PAŃSTWAMI SĄSIEDZKIMI}

Obowiązujący od 1 grudnia 2009 r. traktat lizboński wprowadził istotne zmiany nie tylko w strukturze oraz w zasadach rozwoju współpracy między państwami w ramach UE, lecz także w mechanizmach zacieśniania kooperacji z podmiotami trzecimi, w tym państwami graniczącymi z Unią. Należy w tym miejscu wspomnieć, że na podstawie art. 47 TUE Unia Europejska stała się jednolitą organizacją międzynarodową posiadającą osobowość prawną, tj. została wyposażona m.in. w kompetencje do zawierania porozumień międzynarodowych oraz nawiązywania relacji z organizacjami międzynarodowymi i państwami trzecimi, a także możliwość starania się i uzyskania członkostwa w organizacjach międzynarodowych ${ }^{8}$.

Najważniejsze postanowienia regulujące relacje między UE a państwami sąsiedzkimi zostały zamieszczone w art. 8 ust. 1 TUE, zgodnie z którym Unia rozwija szczególne stosunki $z$ państwami $z$ nia sasiadujacymi, dązac do utworzenia przestrzeni dobrobytu i dobrego sasiedztwa, opartej na wartościach Unii i charakteryzującej się bliskimi i pokojowymi stosunkami opartymi na wspótpracy ${ }^{9}$. W dalszej części artykułu podkreślono, iż do realizacji powyższych celów UE może zawierać z tymi państwami specjalne umowy dotyczące wzajemnych praw, obowiązków oraz podejmowanych wspólnie przedsięwzięć ${ }^{10}$. Rozwój współpracy między UE a państwami sąsiedzkimi regulują ponadto postanowienia art. 212 TFUE. Zgodnie z ust. 1 tego artykułu Unia prowadzi dziatania w zakresie wspótpracy gospodarczej, finansowej i technicznej, w tym pomocy wszczególności

Unii Europejskiej z Rosja, [w:] Europejska Polityka Sasiedztwa Unii Europejskiej. Geneza, doświadczenia, perspektywy, red. J.M. Fiszer, Warszawa 2012, s. 107-127.

O. Tkachuk, Europejska Polityka Sąsiedztwa..., s. 245-247; taż, „Uktad o Stowarzyszeniu..., s. 94-95; P. Marcinkowska, Europejska Polityka Sąsiedztwa..., s. 142-147, 182-186.

8 J.J. Węc, Traktat lizboński. Polityczne aspekty reformy ustrojowej Unii Europejskiej w latach 2007-2009, Kraków 2011, s. 11, 111-118.

9 Traktat o Unii Europejskiejpodpisany w Lizbonie dnia 13 grudnia 2007 r., [w:] Prawo Unii Europejskiej, Bielsko-Biała 2014, s. 181.

10

Tamze. 
$w d z i e d z i n i e$ finansowej, zpaństwami trzecimi innymi niż kraje rozwijajace się $\left[. . .{ }^{11}\right.$. Dodano w nim, że przedsięwzięcia te muszą być zgodne z unijną polityką rozwojową oraz z celami i zasadami działań zewnętrznych UE, natomiast kompetencje w tej sferze włączono do kategorii kompetencji dzielonych Unii i państw członkowskich. Wspomniano również o możliwości zawierania umów międzynarodowych regulujących powyższą współpracę przez UE i państwa członkowskie z jednej strony oraz zainteresowane podmioty trzecie $\mathrm{z}$ drugiej strony (art. 212 ust. 3 TFUE) ${ }^{12}$.

Art. 212 TFUE umieszczono w części V, która została dodana do Traktatu o funkcjonowaniu Unii Europejskiej pod tytułem Dziatania Zewnętrzne Unii. Znalazły się w niej także postanowienia regulujące takie obszary, jak m.in.: wspólna polityka handlowa (art. 206-207), współpraca na rzecz rozwoju (art. 208-211), pomoc humanitarna (art. 214), stosunki UE z organizacjami międzynarodowymi i państwami trzecimi oraz delegatury Unii (art. 220-221). Ponadto w art. 217-218 zawarto postanowienia mówiące o możliwości zawierania z podmiotami trzecimi umów tworzących stowarzyszenie ${ }^{13}$.

Przed wejściem w życie traktatu lizbońskiego współpracę Unii z państwami trzecimi, w tym krajami sąsiedzkimi, regulował od traktatu nicejskiego art. 181a TWE. Treść tego artykułu została przeniesiona do Traktatu o funkcjonowaniu Unii Europejskiej z następującymi zmianami: państwa rozwijające się nie zostały objęte współpracą gospodarczą, finansową i techniczną rozwijaną przez UE z podmiotami trzecimi w myśl art. 212 TFUE; ust. 1 tego artykułu uzupełniono stwierdzeniem: $w$ tym pomocy $w$ szczególności $w$ dziedzinie finansowej; umieszczono wymóg zgodności podejmowanych w ramach omawianego artykułu przedsięwzięć z działaniami zewnętrznymi UE; podkreślono, że wszystkie decyzje związane z realizacją celów wynikających z art. 212 TFUE są przyjmowane przez Radę i Parlament Europejski na podstawie zwykłej procedury prawodawczej ${ }^{14}$.

Jak zatem można zauważyć, postanowienia regulujące rozwój współpracy między UE a państwami sąsiedzkimi umieszczono zarówno w Traktacie o Unii Europejskiej, jak i w Traktacie o funkcjonowaniu Unii Europejskiej. W drugim z tych dokumentów zawarto artykuły odnoszące się do działań zewnętrznych Unii, w tym wyposażające ją w możliwość podejmowania działań w ramach rozwoju współpracy w trzech dziedzinach (gospodarczej, finansowej i technicznej) oraz udzielania pomocy (nie tylko finansowej) państwom trzecim innym niż kraje rozwijające się, a także regulujące stosunki z organizacjami międzynarodowymi. Natomiast we wspomnianym art. 8, który nie został włączony do części V TFUE, lecz znalazł się w Traktacie o Unii Europejskiej, zawarto bardzo ogólne sformułowania dotyczące kształtowania relacji z państwami sąsiedzkimi ${ }^{15}$.

11 Traktat o funkcjonowaniu Unii Europejskiej podpisany w Lizbonie dnia 13 grudnia 2007 r., [w:] Prawo Unii Europejskiej, Bielsko-Biała 2014, s. 109.

12 Tamże.

13 Tamże, s. 106-116.

14 A. Kalicka-Mikołajczyk, Ramy prawne i zasady unijnej Europejskiej Polityki Sasiedztwa wobec partnerów wschodnich, Wrocław 2013, s. 29-32.

15 Tamże, s. 29-32. 
W Traktacie o Unii Europejskiej umieszczono również tytuł V (Postanowienia ogólne o dziataniach zewnętrznych Unii i postanowienia szczególne dotyczace Wspólnej Polityki Zagranicznej i Bezpieczeństwa), w którym podkreślono, że Unia dąży do rozwijania stosunków i budowania partnerstwa z państwami trzecimi oraz z organizacjami międzynarodowymi, regionalnymi lub światowymi [... $]^{16}$, zgodnie $\mathrm{z}$ wartościami i zasadami obowiązującymi w ramach UE (art. 21 ust. 1 TUE) ${ }^{17}$.

Jednak we wszystkich powyższych zapisach brak jest bezpośredniego odniesienia do Europejskiej Polityki Sąsiedztwa, której realizacja w dalszym ciągu opiera się na aktach wewnętrznych UE, tj. komunikatach przyjmowanych przez Komisję Europejską $(\mathrm{KE})^{18}$, m.in.: Europejska Polityka Sasiedztwa. Dokument strategiczny z maja 2004 r. ${ }^{19}$, W sprawie wzmocnienia Europejskiej Polityki Sasiedztwa z grudnia 2006 r. ${ }^{20}$, Silna Europejska Polityka Sasiedztwa z grudnia 2007 r. ${ }^{21}$, Nowa koncepcja dziatań w obliczu zmian zachodzacych w sasiedztwie z maja 2011 r. ${ }^{22}$, Przeglad Europejskiej Polityki Sasiedztwa. Wspólny komunikat Komisji Europejskiej do Parlamentu Europejskiego, Rady, Europejskiego Komitetu Ekonomiczno-Spotecznego i Komitetu Regionów z listopada 2015 r. ${ }^{23}$ We wszystkich tych dokumentach dokonano przeglądu dotychczasowej realizacji celów i zadań Europejskiej Polityki Sąsiedztwa oraz wskazano kroki, które należałoby podjąć, by wzmocnić jej efektywnośćc $c^{24}$ Ponadto, pomijając w art. 8 TUE określenie „Europejska Polityka Sąsiedztwa”, Unia Europejska zachowała możliwość rozwoju współpracy w oparciu o jego postanowienia, w tym zawierania „specjalnych umów” z państwami sąsiedzkimi nieuczestniczącymi w EPS (np. Federacją Rosyjską)25.

16 Traktat o Unii Europejskiej..., s. 191.

17 Tamże.

18 A. Kalicka-Mikołajczyk, Ramy prawne..., s. 28-32.

19 Communication from the Commission, European..., s. 1-35.

20 W sprawie wzmocnienia Europejskiej Polityki Sasiedztwa. Komunikat Komisji dla Rady i Parlamentu Europejskiego z 4 grudnia 2006 r., $\mathrm{KOM}(2006) 726$ wersja ostateczna, s. 1-16.

21 Silna europejska polityka sasiedztwa. Komunikat Komisji do Parlamentu Europejskiego i Rady z 5 grudnia 2007 r., $\operatorname{KOM(2007)~} 774$ wersja ostateczna, s. 1-14.

22 Nowa koncepcja dziatań w obliczu zmian zachodzacych w sasiedztwie. Wspólny komunikat do Parlamentu Europejskiego, Rady, Europejskiego Komitetu Ekonomiczno-Spotecznego i Komitetu Regionów z 25 maja 2011 r., $\operatorname{KOM(2011)~} 303$ wersja ostateczna, s. 1-45.

23 Przegląd Europejskiej Polityki Sasiedztwa. Wspólny komunikat do Parlamentu Europejskiego, Rady, Europejskiego Komitetu Ekonomiczno-Spotecznego i Komitetu Regionów z 18 listopada 2015 r., JOIN(2015) 50 final, s. 1-25.

24 A. Nitszke, $W$ kierunku nowej Europejskiej Polityki Sąsiedztwa Unii Europejskiej, „Rocznik Integracji Europejskiej” 2016, nr 10, s. 381-396, [online] http://rie.amu.edu.pl/wp-content/uploads/2017/01/ rie10-2016-24.pdf, https://doi.org/10.14746/rie.2016.10.24, 15 IV 2018; A. Kalicka-Mikołajczyk, Ramy prawne..., s. 32-42; O. Tkachuk, Europejska Polityka Sąsiedztwa..., s. 245-246; I. Lyubashenko, Podstawy normatywne..., s. 25-28.

25 A. Sęk, Seminarium „Europejska Polityka Sasiedztwa i Traktat z Lizbony - co się zmienito?”, Centrum Inicjatyw Międzynarodowych. Blog, 28 III 2013, [online] http://blog.centruminicjatyw. org/2013/03/seminarium-europejska-polityka-sasiedztwa-i-traktat-z-lizbony-co-sie-zmienilo/, $11 \mathrm{~V}$ 2018. 


\section{ZMIANY INSTYTUCJONALNE MAJĄCE WPŁYW NA REALIZACJĘ DZIAŁAŃ ZEWNĘTRZNYCH UNII EUROPEJSKIEJ}

Wpływ traktatu lizbońskiego na zasady funkcjonowania UE nie ogranicza się do zmiany i rozszerzenia podstaw prawnych realizacji celów i zadań UE. Tworzy także nowe organy i stanowiska oraz w znaczący sposób wzmacnia kompetencje dotychczasowych organów i instytucji Unii odpowiedzialnych za rozwój współpracy z organizacjami międzynarodowymi i państwami trzecimi, w tym krajami sąsiedzkimi. Przede wszystkim doszło do istotnego wzmocnienia pozycji Rady Europejskiej (RE) poprzez uzyskanie statusu instytucji oraz powołanie jej stałego przewodniczącego ${ }^{26}$. Zgodnie z art. 15 ust. 1 oraz 26 ust. 1 TUE, RE nadaje Unii impulsy niezbędne do jej rozwoju i określa ogólne kierunki i priorytety polityczne $e^{27}$, a także określa strategiczne interesy Unii, ustala cele oraz określa ogólne wytyczne wspólnej polityki zagranicznej i bezpieczeństwa ${ }^{28}$. Ponadto w traktacie stwierdzono, że RE przyjmuje decyzje dotyczące strategicznych interesów i celów UE w zakresie wspólnej polityki zagranicznej bezpieczeństwa oraz pozostałych obszarów związanych z działaniami zewnętrznymi Unii, przy czym mogą one odnosić się do relacji z państwami trzecimi lub regionami bądź do wybranego problemu. Mogą być w nich zawarte informacje na temat ich czasu trwania lub instrumentów, które mają zostać oddane do dyspozycji przez UE i państwa członkowskie ${ }^{29}$. Z kolei stały przewodniczący RE, wybierany przez Radę Europejską większością kwalifikowaną na okres 2,5 roku, wyposażony został w następujące kompetencje: przewodniczenie RE, prowadzenie jej prac (dzięki czemu przewodniczący gwarantuje ich ciągłość oraz stara się zapewnić spójność w RE), reprezentowanie UE na zewnątrz w kwestiach związanych ze wspólną polityką zagraniczną i bezpieczeństwa ${ }^{30}$. Obecnie funkcję tę pełni Donald Tusk ${ }^{31}$.

Kolejną znaczącą zmianą instytucjonalną w prowadzoną przez traktat lizboński było ustanowienie urzędu Wysokiego Przedstawiciela Unii do spraw zagranicznych i polityki bezpieczeństwa. Jest on mianowany przez Radę Europejską większością kwalifikowaną, za zgodą przewodniczącego Komisji Europejskiej oraz jednocześnie sprawuje funkcję stałego przewodniczącego Rady do Spraw Zagranicznych i jednego z wiceprzewodniczących KE. Odpowiada on za prowadzenie i realizację wspólnej polityki zagranicznej i bezpieczeństwa oraz uczestniczy w jej opracowaniu, a także zapewnia wdrożenie w życie decyzji podejmowanych przez Radę i RE ${ }^{32}$. Ponadto Wysoki Przed-

26 J.J. Węc, Traktat lizboński..., s. 160; tenże, Spór o ksztatt ustrojowy Wspólnot Europejskich i Unii Europejskiej w latach 1950-2010. Między idea ponadnarodowości a wspótpraca międzyrządowa. Analiza politologiczna, Kraków 2012, s. 531.

27 Traktat o Unii Europejskiej..., s. 184.

28 Tamże, s. 194.

29 Tamże, s. 192.

30 Tamże, s. 185; J.J. Węc, Traktat lizboński..., s. 161.

31 Rada Europejska, Donald Tusk. Przewodniczacy Rady Europejskiej, 30 X 2017, [online] http://www. consilium.europa.eu/pl/european-council/president/biography/, 15 IV 2018.

32 J.J. Węc, Traktat lizboński..., s. 173-176; Traktat o Unii Europejskiej..., s. 188-189, 194-195. 
stawiciel Unii, zgodnie z art. 18 ust. 4, czuwa nad spójnościa dziatań zewnętrznych Unii. Odpowiada w ramach Komisji za jej obowiązki w dziedzinie stosunków zewnętrznych $i$ koordynację innych aspektów dziatań zewnętrznych Unii $[. . .]^{33}$. Reprezentuje on również UE w kwestiach związanych ze wspólną polityką zagraniczną i bezpieczeństwa, przedstawia stanowisko Unii $\mathrm{w}$ organizacjach międzynarodowych lub na konferencjach międzynarodowych oraz realizuje dialog polityczny z podmiotami trzecimi ${ }^{34}$. Od 1 listopada 2014 r. funkcję tę pełni Federica Mogherini ${ }^{35}$. Razem z Komisją Europejską w 2015 r. przygotowała ona wspomniany komunikat Przeglad Europejskiej Polityki Sasiedztwa, w którym wskazała konieczność podjęcia kroków na rzecz wzmocnienia stabilności w krajach partnerskich w różnych dziedzinach i zacieśnienia współpracy w sferze bezpieczeństwa, podkreśliła gotowość UE do podjęcia rozmów w sprawie określenia nowych priorytetów partnerstwa, a także zwróciła uwagę na potrzebę zwiększenia spójności działań podejmowanych przez UE i państwa członkowskie. Z kolei wśród głównych priorytetów we wzajemnej współpracy wymieniła: rozwój gospodarczy na rzecz stabilizacji, wymiar bezpieczeństwa, migrację i mobilność. W komunikacie poruszono również kwestię pogłębienia współpracy regionalnej, w tym w ramach istniejących programów, takich jak Unia dla Śródziemnomorza i Partnerstwo Wschodnie, a także wskazano konieczność uelastycznienia instrumentów finansowych oraz poszukiwania dodatkowych środków finansowych na realizację celów EPS ${ }^{36}$.

Wykonując swoje zadania, Wysoki Przedstawiciel Unii korzysta ze wsparcia Europejskiej Służby Działań Zewnętrznych (ESDZ). Podstawa traktatowa do powołania tego organu została zawarta w art. 27 ust. 3 TUE. W skład ESDZ wchodzą urzędnicy odpowiednich służb Sekretariatu Generalnego Rady i KE oraz personelu oddelegowanego przez krajowe służby dyplomatyczne ${ }^{37}$. Jej organizacja i zasady funkcjonowania zostały określone w decyzji Rady z 26 lipca 2010 r. Oficjalnie ESDZ rozpoczęła działalność 1 grudnia 2010 r., natomiast w praktyce - 1 stycznia 2011 r. $^{38}$ Służba ta odpowiada za rozwój stosunków dyplomatycznych oraz partnerstwa strategicznego z organizacjami międzynarodowymi i państwami trzecimi, w tym krajami sąsiedzkimi. Współdziała ona przy tym ze służbami dyplomatycznymi państw członkowskich UE, ONZ i innymi. Jednym z zadań ESDZ jest zapewnienie spójności działań zewnętrznych Unii Europejskiej ${ }^{39}$.

Oprócz powyższych organów i instytucji, na podstawie traktatu lizbońskiego zmian doświadczyły również: Parlament Europejski (PE), Komisja Europejska i Rada Unii

33 Traktat o Unii Europejskiej..., s. 188-189.

34 Tamże, s. 195.

35 Ministerstwo Spraw Zagranicznych RP, Wysoki Przedstawiciel Unii do Spraw Zagranicznych i Polityki Bezpieczeństwa, [online] http://www.msz.gov.pl/pl/p/msz_pl/polityka_zagraniczna/unia_europejska/obszary/wpzib/wpzib/wpzib_wysoki_przedstawiciel, 15 IV 2018.

36 Przeglad Europejskiej Polityki Sąsiedztwa..., s. 1-25.

37 Traktat o Unii Europejskiej..., s. 195.

38 A. Chojan, Europejska Stużba Dziatań Zewnętrznych - postęp czy regres w politycznej integracji Europy?, „Myśl Ekonomiczna i Polityczna” 2012, nr 1 (36), s. 153.

39 Unia Europejska, Europejska Stużba Dziatań Zewnętrznych (ESDZ), [online] https://europa.eu/ european-union/about-eu/institutions-bodies/eeas_pl, 15 IV 2018. 
Europejskiej. PE pełni funkcję prawodawczą i budżetową, sprawuje kontrolę polityczną oraz udziela konsultacji w sprawach określonych w traktacie ${ }^{40}$. Traktat lizboński wzmocnił jego kompetencje dotyczące m.in. zawierania umów międzynarodowych; wprowadzono obowiązek udzielania przez PE zgody na decyzję Rady w sprawie zawarcia umów regulujących obszary, w których stosowana jest zwykła procedura ustawodawcza lub specjalna procedura ustawodawcza (jeżeli ta procedura wymaga zgody $\mathrm{PE})^{41}$. Z kolei KE, zgodnie $\mathrm{z}$ art. 17 ust. 1 TUE, podejmuje odpowiednie kroki na rzecz realizacji ogólnego interesu UE, a jej przewodniczący uzyskał prawo do wyrażania zgody na mianowanie lub odwoływanie Wysokiego Przedstawiciela Unii oraz formułowania wobec niego wytycznych ${ }^{42}$. Jeżeli chodzi o Radę Unii Europejskiej, to w pierwszej kolejności należy podkreślić, że razem z RE określa i realizuje ona wspólną politykę zagraniczną i bezpieczeństwa, działając na zasadzie jednomyślności, a współpracując z Wysokim Przedstawicielem Unii, odpowiada za zapewnienie jednolitości, spójności i skuteczności działań UE. Rada UE składa się z Rady do Spraw Ogólnych oraz Rady do Spraw Zagranicznych ${ }^{43}$. Ostatnia z nich na podstawie art. 16 ust 6 TUE opracowuje dziatania zewnętrzne Unii na podstawie strategicznych kierunków określonych przez Radę Europejska oraz zapewnia spójność dziatań Unii ${ }^{44}$. Ponadto Rada podejmuje decyzje, które zawierają stanowisko Unii Europejskiej wobec określonego problemu o charakterze geograficznym lub przedmiotowym, natomiast państwa członkowskie uzgadniają swoją politykę narodową z tym stanowiskiem ${ }^{45}$.

Jak można zauważyć, traktat lizboński doprowadził do znacznego wzmocnienia zarówno instytucji ponadnarodowych, jak i międzyrządowych UE. Przedstawione zmiany miały na celu zwiększenie efektywności działań podejmowanych przez Unię poprzez zapewnienie większej spójności na płaszczyźnie wewnętrznej (we współdziałaniu między poszczególnymi instytucjami Unii, a także między UE i jej państwami członkowskimi) oraz zewnętrznej (we współpracy między UE i jej państwami członkowskimi a podmiotami trzecimi). W tym celu powołano Wysokiego Przedstawiciela Unii, który jednocześnie jest jednym z wiceprzewodniczących KE, przewodniczy Radzie do Spraw Zagranicznych, uczestniczy w pracach Rady Europejskiej, a także zapewnia wdrażanie w życie decyzji Rady i $\mathrm{RE}^{46}$. Jest on zatem pewnego rodzaju łączem między KE, która - jak pokazuje rzeczywistość - jest głównym twórcą założeń i celów EPS, a także uczestniczy w ich wdrażaniu w życie, a RE i Radą, które podejmują decyzje dotyczące realizacji EPS (w przypadku RE są to decyzje polityczne o charakterze strategicznym $)^{47}$. Potwierdza to także, że rozwój współpracy między UE i państwami

$40 \quad$ Traktat o Unii Europejskiej..., s. 184.

${ }_{41}$ Tamże, s. 112-113; J.J. Węc, Traktat lizboński..., s. 196.

42

Traktat o Unii Europejskiej..., s. 186-187; J.J. Węc, Traktat lizboński..., s. 189-190.

3 Traktat o Unii Europejskiej..., s. 186, 193-194; J.J. Węc, Traktat lizboński..., s. 164-166.

44 Traktat o Unii Europejskiej..., s. 186.

45 Tamże, s. 196.

46 Tamże, s. 184, 188-189, 195.

47 I. Lyubashenko, Europejska Polityka Sasiedztwa..., s. 156-159. 
sąsiedzkimi pozostaje $\mathrm{w}$ gestii instytucji międzyrządowych z ograniczonym udziałem instytucji ponadnarodowych.

Niemniej jednak, mimo omówionych zmian instytucjonalnych, w dalszym ciągu pojawiają się problemy związane z uzgodnieniem wspólnego stanowiska UE i państw członkowskich w sprawach polityki zewnętrznej. Należy dodać, że obowiązująca globalna strategia Unii: Wspólna wizja, wspólne dziatanie: Silniejsza Europa, zawierająca m.in. punkty dotyczące współpracy UE z państwami sąsiedzkimi, została przyjęta dopiero w 2016 r. ${ }^{48}$ Poprzednią strategię: Bezpieczna Europa w lepszym świecie opracował w 2003 r. ówczesny Wysoki Przedstawiciel do spraw wspólnej polityki zagranicznej i bezpieczeństwa Javier Solana ${ }^{49}$. Oznacza to, że przez 13 lat Unia pozostawała bez dokumentu, który kompleksowo określałby kierunki działań zewnętrznych UE.

\section{ZAKOŃCZENIE}

Podsumowując powyższe rozważania, należy zauważyć, że stosunki między UE a państwami sąsiedzkimi regulują art. 8 TUE oraz artykuły zawarte w części V TFUE, jednak w żadnym z tych traktatów Europejska Polityka Sąsiedztwa nie jest wymieniana z nazwy. Ponadto sformułowania zawarte w powyższych artykułach mają charakter bardzo ogólny, w związku z czym realizacja celów i zadań analizowanej polityki opiera się na dokumentach wewnętrznych przyjmowanych przez instytucje UE, takich jak komunikaty KE. Pod wpływem zmian zachodzących na arenie międzynarodowej, w tym w najbliższym otoczeniu Unii, opracowywane i przyjmowane są nowe dokumenty dostosowujące EPS do współczesnych wyzwań i zagrożeń, m.in. kryzysu migracyjnego, wojny w Syrii czy destabilizacji sytuacji na wschodzie Ukrainy. Z jednej strony zatem postanowienia zawarte w Traktacie o Unii Europejskiej oraz Traktacie o funkcjonowaniu Unii Europejskiej w bardzo uproszczony sposób regulują współpracę Unii z państwami z nią sąsiadującymi, nie wymieniając żadnych szczegółowych zadań lub instrumentów, a tym samym w pewien sposób marginalizując EPS. Z drugiej natomiast strony ta ogólnikowość pozwala szybko i elastycznie reagować na zmiany zachodzące na arenie międzynarodowej oraz formułować cele i zadania EPS dostosowane do nowej sytuacji międzynarodowej.

Ponadto traktat lizboński znacząco wpływa na strukturę instytucjonalną Unii Europejskiej, wzmacniając kompetencje powołanych wcześniej instytucji UE oraz tworząc podstawę prawną do ustanowienia nowych stanowisk i organów odpowiedzialnych za opracowywanie i realizację działań zewnętrznych Unii, takich jak: stały przewodniczący

48 Globalna strategia na rzecz polityki zagranicznej i bezpieczeństwa Unii Europejskiej, Bruksela, 28 VI 2016, 10715/16, s. 1-45, [online] http://data.consilium.europa.eu/doc/document/ST-10715-2016-INIT/pl/pdf, 11 V 2018.

49 Bezpieczna Europa w lepszym świecie. Europejska Strategia Bezpieczeństwa, Bruksela, 12 XII 2003, [w:] Europejska Strategia Bezpieczeństwa. Bezpieczna Europa w lepszym świecie, Luksemburg 2009, s. 3, 10, 27-43, [online] https://www.bbn.gov.pl/ftp/dok/01/strategia_bezpieczenstwa_ue_2003. pdf, https://doi.org/10.2860/16160, 11 V 2018. 
RE, Wysoki Przedstawiciel Unii do spraw zagranicznych i polityki bezpieczeństwa, Europejska Służba Działań Zewnętrznych. Jednym z celów podjętych w tym zakresie decyzji było wzmocnienie spójności działań zewnętrznych UE, a tym samym zwiększenie ich skuteczności. Jednak problemu tego, jak pokazuje obecna sytuacja w Unii Europejskiej (np. Brexit, kryzys migracyjny), dotychczas nie udało się rozwiązać. W dalszym ciągu odczuwalny jest brak odpowiednich instrumentów, które zapewniłyby efektywną koordynację działań zewnętrznych między państwami członkowskimi UE.

\section{BIBLIOGRAFIA}

Bartczak K., Jongberg K., Dokumenty informacyjne o Unii Europejskiej - 2017. Europejska Polityka Sasiedztwa, Parlament Europejkki, [online] http://www.europarl.europa.eu/RegData/ etudes/fiches_techniques/2013/060504/04A_FT(2013)060504_PL.pdf.

Bezpieczna Europa w lepszym świecie. Europejska Strategia Bezpieczeństwa, Bruksela, 12 XII 2003, [w:] Europejska Strategia Bezpieczeństwa. Bezpieczna Europa w lepszym świecie, Luksemburg 2009, [online] https://www.bbn.gov.pl/ftp/dok/01/strategia_bezpieczenstwa_ ue_2003.pdf, https://doi.org/10.2860/16160.

Chojan A., Europejska Stużba Dziatań Zewnętrznych - postęp czy regres w politycznej integracji Europy?, „Myśl Ekonomiczna i Polityczna” 2012, nr 1 (36).

Communication from the Commission, European Neighbourhood Policy. Strategy Paper, Brussels, 12 V 2004, COM(2004) 373 final.

Globalna strategia na rzecz polityki zagranicznej i bezpieczeństwa Unii Europejskiej, Bruksela, 28 VI 2016, 10715/16, [online] http://data.consilium.europa.eu/doc/document/ ST-10715-2016-INIT/pl/pdf.

Kalicka-Mikołajczyk A., Ramy prawne i zasady unijnej Europejskiej Polityki Sasiedztwa wobec partnerów wschodnich, Wroctaw 2013.

Lyubashenko I., Europejska Polityka Sąsiedztwa Unii Europejskiej wobec państw Europy Wschodniej, Toruń-Łysomice 2012.

Lyubashenko I., Podstawy normatywne Europejskiej Polityki Sasiedztwa, [w:] Europejska Polityka Sąsiedztwa Unii Europejskiej, red. M. Pietraś, K. Stachurska-Szczesiak, J. Misiągiewicz, Lublin 2012.

Marcinkowska P., Europejska Polityka Sasiedztwa. Unia Europejska i jej sasiedzi - wzajemne relacje i wyzwania, Warszawa 2011.

Ministerstwo Spraw Zagranicznych RP, Wysoki Przedstawiciel Unii do Spraw Zagranicznych i Polityki Bezpieczeństwa, [online] http://www.msz.gov.pl/pl/p/msz_pl/polityka_zagraniczna/ unia_europejska/obszary/wpzib/wpzib/wpzib_wysoki_przedstawiciel.

Nitszke A., W kierunku nowej Europejskiej Polityki Sasiedztwa Unii Europejskiej, „Rocznik Integracji Europejskiej" 2016, nr 10, [online] http://rie.amu.edu.pl/wp-content/uploads/2017/01/rie10-2016-24.pdf, https://doi.org/10.14746/rie.2016.10.24.

Nowa koncepcja dziatań wobliczu zmian zachodzacych w sasiedztwie. Wspólny komunikat do Parlamentu Europejskiego, Rady, Europejskiego Komitetu Ekonomiczno-Spotecznego i Komitetu Regionów z 25 maja 2011 r., $\operatorname{KOM(2011)~} 303$ wersja ostateczna. 
Piskorska B., Implikacje Europejskiej Polityki Sasiedztwa dla "partnerstwa strategicznego" Unii Europejskiej z Rosja, [w:] Europejska Polityka Sasiedztwa Unii Europejskiej. Geneza, doświadczenia, perspektywy, red. J.M. Fiszer, Warszawa 2012.

Przegląd Europejskiej Polityki Sąiedztwa. Wspólny komunikat do Parlamentu Europejskiego, Rady, Europejskiego Komitetu Ekonomiczno-Spotecznego i Komitetu Regionów z 18 listopada 2015 r., JOIN(2015) 50 final.

Rada Europejska, Donald Tusk. Przewodniczacy Rady Europejskiej, 30 X 2017, [online] http:// www.consilium.europa.eu/pl/european-council/president/biography/.

Sęk A., Seminarium „Europejska Polityka Sąsiedztwa i Traktat z Lizbony - co się zmienito?”, Centrum Inicjatyw Międzynarodowych. Blog, 28 III 2013, [online] http://blog.centruminicjatyw.org/2013/03/seminarium-europejska-polityka-sasiedztwa-i-traktat-z-lizbony-co-sie-zmienilo/.

Silna europejska polityka sąsiedztwa. Komunikat Komisji do Parlamentu Europejskiego i Rady z 5 grudnia 2007 r., $\operatorname{KOM}(2007) 774$ wersja ostateczna.

Tkachuk O., „Uktad o Stowarzyszeniu między Uniq Europejska a Ukrainq” - najważniejsze postanowienia oraz znaczenie dla Ukrainy, [w:] Ukraina. 25 lat na drodze niepodlegtości, red. P. Pietnoczka, H. Stroński, Olsztyn 2017.

Tkachuk O., Europejska Polityka Sąsiedztwa, [w:] Polityki europejskie. Perspektywa finansowa UE 2014-2020, red. A. Nitszke, Kraków 2015.

Traktat o funkcjonowaniu Unii Europejskiej podpisany w Lizbonie dnia 13 grudnia 2007 r., [w:] Prawo Unii Europejskiej, Bielsko-Biała 2014.

Traktat o Unii Europejskiej podpisany w Lizbonie dnia 13 grudnia 2007 r., [w:] Prawo Unii Europejskiej, Bielsko-Biała 2014.

Unia Europejska, Europejska Stużba Dziatań Zewnętrznych (ESDZ), [online] https://europa. eu/european-union/about-eu/institutions-bodies/eeas_pl.

$W$ sprawie wzmocnienia Europejskiej Polityki Sasiedztwa. Komunikat Komisji dla Rady i Parlamentu Europejskiego z 4 grudnia 2006 r., $\operatorname{KOM(2006)} 726$ wersja ostateczna.

Węc J.J., Spór o ksztatt ustrojowy Wspólnot Europejskich i Unii Europejskiej w latach 1950-2010. Między idea ponadnarodowości a wspótpraca międzyrządową. Analiza politologiczna, Kraków 2012.

Węc J.J., Traktat Lizboński. Polityczne aspekty reformy ustrojowej Unii Europejskiej w latach 2007-2009, Kraków 2011.

Mgr Olesia TKACHUK, doktorantka w Katedrze Studiów nad Procesami Integracyjnymi w Instytucie Nauk Politycznych i Stosunków Międzynarodowych UJ. Członkini Polskiego Towarzystwa Studiów Europejskich. Uczestniczka Studium Dziennikarskiego Uniwersytetu Pedagogicznego im. KEN w Krakowie (2013-2015). Uczestniczka międzynarodowych i ogólnopolskich konferencji, autorka kilku artykułów naukowych poświęconych obszarowi poradzieckiemu, integracji europejskiej, Europejskiej Polityce Sąsiedztwa (m.in.: Wptyw konfliktu zbrojnego na Ukrainie na sytuacje gospodarczą państw poradzieckich, „Uktad o Stowarzyszeniu między Unia Europejska a Ukraina” - najważniejsze postanowienia oraz znaczenie dla Ukrainy). Zainteresowania naukowe: integracja europejska, współpraca UE z republikami poradzieckimi. 